УДК 821. 161.2-1

Веретюк Т. В.

кандидат філологічних наук, викладач кафедри української та світової літератур Харківського національного педагогічного університету імені Г. С. Сковороди

\title{
ТЕМА ВІЙНИ В ПОЕТИЧНІЙ СПАДЩИНІ ІГОРЯ МУРАТОВА
}

Стаття присвячена дослідженню воєнної тематики в поетичних творах Ігоря Муратова в контексті сочреалістичної літератури. Детально проаналізовані вірші поета, дві поеми «Залізом і кров'ю» та «Розчахнута брама», а також сюїта «Партизан Лобода». Дослідниия наголошує на характері й особливостях відповідного історичного часу, щуо мали безперечний вплив на формування таланту письменника.

Ключові слова: сочреалізм, війна, героїзм, партіотизм, конщтабір.

Эта статья посвящается изучению военной тематики в поэтических произведениях Игоря Муратова в контексте сочреалистической литературы. Детально проанализировань стихи поэта, две поэмы «Железом и кровью» и «Распахнутые врата», а также сюита «Партизан Лобода». Исследовательница акиентирует внимание на характере $u$ особенностях соответственного исторического времени, которые имели бесспорное влияние на формирование таланта писателя.

Ключевые слова: сочреализм, война, патриотизм, конилагерь.

The article is devoted to research of the military theme in Ihor Muratov's poetry in the context of Socialist-realism literature. The poet's verses, two poems «With Iron and Blood» and "Gate Wide-Open», and also the suite «Loboda the Partisan» were analyzed in detail. The researcher emphasized on the character and peculiarities of the corresponding historical time, which has had the doubtless influence on the formation of the writer's talent.

Keywords: socialist realism, war, heroism, patriotism, concentration camp. 
На сьогодні тема війни актуальна не лише в українській, а й у світовій літературі. Не дивно, що значну кількість творів воєнної тематики було створено саме у XX столітті, адже це період двох світових війн та емоційних переживань навколо воєнних реалій, що посідають чільне місце як у серцях очевидців тих страшних подій, так і в серцях тих, хто не залишився байдужим до найтяжчих суспільних потрясінь. Про це свідчать твори багатьох авторів: Е. Гемінгвея, Г. Бьолля, Е.-М. Ремарка, А. Камю, П. Целана, О. Твардовського, А. Ахматової, Ю. Яновського, О. Гончара, О. Довженка, Ліни Костенко та інших. Свого часу В. Агєєва, розмірковуючи над незгасним інтересом до воєнної пам’яті, цілком слушно стверджувала: «Війна проявила, оголила приховані в повсякденному плині життя конфлікти, протистояння добра $i$ зла, такі злети героїзму і безодні морального падіння, щяо в роздумах про те, щэо людина може, в чому суть, смисл ї̈ життя, до воєнного матеріалу звертаються знов і знов» [Агеєва 1989:208].

Особливого висвітлення тема війни набула в українській соцреалістичній літературі - явищі доволі суперечливому й неоднозначному, розвиток i особливості якого тісно пов'язані 3 історичними подіями та політичними змінами в СРСР. Принаймні для української радянської літератури воєнного й повоєнного періоду характерні свої специфічні риси [Куцевол 2011:22].

Перші статті та патріотичні вірші українських поетів 3'явились на газетних шпальтах уже 23-24 червня 1941 року. Так, у газеті «Правда» було надруковано «Ми йдемо на бій» П. Тичини, по радіо читали «Клятву» М. Бажана, поезії М. Рильського, Л. Первомайського [ІУЛ 1998:5].

Загалом, для творів воєнної тематики радянського періоду характерними були мотиви патріотизму, високий громадянський пафос, пристрасна публіцистичність [Куцевол 2011:22]. Утім, можна сміливо стверджувати, що тема війни набула тоді доволі неоднозначного потрактування й різнопланового ідейного освітлення, що, у свою чергу, стало причиною появи в свідомості читача полярних емоційно-розумових оцінок. 
Не раз звертався до теми війни й Ігор Муратов. Тим часом у працях, присвячених аналізу ліричної спадщини цього талановитого поета, тема війни не стала предметом окремого зацікавлення, що й зумовлює актуальність нашої публікації.

Ми маємо на меті здійснити аналіз специфіки теми війни в ліричному доробку Муратова, починаючи від 1940 року й до останньої збірки поета, датованої 1973 р., а також спробуємо розглянути філософський аспект поезій воєнної тематики як віддзеркалення одвічних проблем людського буття: добра i зла, життя і смерті, моралі тощо.

Воєнний час у творах І. Муратова змальовується як вимушена сувора реальність, котра, звичайно, не відступає від усіх проявів людського життя, але разом із тим не є природною й за своєю суттю суперечить людському єству. Уперше про війну І. Муратов писав у поезії «Нездолана Іспанія - вперед», де змалював події громадянської війни 1936-1939 років у цій країні: «Нездолана Іспанія - вперед! / Ти вмієш смерть в обличчя зустрічати, - / Навчись же ворога вбачати й за плечем, / I зрадників улесливих карати / Святої справедливості мечем» [Муратов 1937:66].

У цих рядках, як і в подальших віршах, війна постає як біда й усвідомлюється як руйнівна сила, та, попри це, вона $є$ жорстокою вимушеною неминучістю, у якій необхідно вистояти й перемогти. У поезіях І. Муратова немає простих опоетизованих історій про бойові подвиги, якими б автор захоплювався і які б звеличував. Він порушує проблеми морального характеру: вірність високим ідеалам, перевірка духовної цінності людини в умовах, що потребують граничного напруження сил та самопожертви. I все ж загальний тон поезій оптимістичний: битва заради життя, а сила воїнів - у тому, що вони «і в слушний свій час, $i$ у смертний свій час» [Муратов 1941:11] вірять у силу життя та майбутню перемогу.

Цікавою 3 цього погляду є поезія «Матуся» (перша назва - «Романтична балада»), у якій усе вражає силою почуття, оригінальністю задуму, шляхетністю і справжньою піднесеністю думки. Мати-українка, дізнавшись, що ії син поранений 
на фінському фронті, поспішає до нього. I раптом вона бачить, як у лісовій пущі падають один по одному поранені бійці. Вона зупиняється біля них, а сосни їй шумлять: «Іди, не зупиняйся: / На озері, один, / Заметений снігами, / Лежить твій милий син...» [Муратов 1972:393]. А мати їм відповідає: «Ви серцем здичавіли / У тьмі дичавини, / Мовчіть, зловісні сосни, / Це все - мої сини!» / ...I хустку їм на рани / Матуся розрива, / I зіллям їх изілющзим / 3 любов’ю напува» [Муратов 1972:394].

I коли, врешті-решт, матір приходить до свого сина, то бачить, як «...від багаття / Глибокий сніг розтав; / I в білому наметі / Спокійно диха - він, / Її коханий голуб, / Їі єдиний син; / I наче на сторожі / Його щүасливих снів, / За ним i дні і ночі / Пильнують ніжні очі / Незнаних матерів» [Муратов 1972:394].

Певна романтично-баладна умовність увиразнила зображення зворушливої материнської любові до сина, пораненого на фронті, поєднаної з піклуванням незнаних матерів та великою святою любов’ю матері-Вітчизни до своїх синів. Цей важливий ідейний мотив, локалізований скупими фабулами, набув особливо тонкої емоціональної виразності.

Натомість персонажі поезій «Ковток води» i «Слово до живих»антиподи. Один ковток - «за перше слово зради» [Муратов 1962:264] відокремлює колишнього воїна від його товаришів по полону. Той, хто загинув на війні, звертаючись до живих, має право нагадувати їм: «... Кричу, сповіщаю, / Потойбічною пам'яттю мщу: / Не прощуав, не простив, не прощъаю, / Не дозволю простить, / Не прощуу!〉 [Муратов 1982:115]. У вірші «Слово до живих» світ авторського «я» співвідноситься з родовими рисами людини і з загальнолюдськими проблемами. Початок поезії - це палкий заклик від імені жертв Моабіту, Треблінки, всіх фашистських катівень: пам'ять виступає тут структурантом історичного часу, що зреалізований у філософсько-естетичній площині морального обов’язку людини.

Пам’ять ліричного героя I. Муратова, як прояв історичного часу, має багато глибоких карбів, що були залишені воєнним лихоліттям: «Я знов утечу, / $i$, ненависті повен, - до зброї, / В атаки, / в окопи, / в прості рядові, / у герої. / Помру $i$ 
воскресну, / згнию - відроджуся стократно. / Щоб світ задротований, / чорний, / тюремний, / загратний / Заднів після ночі / й залюднилися мертві оселі. / O сестри й братове! / Ви чуєте? Стогнуть голодні. / Розчавимо війни / сьогодні, сьогодні, сьогодні, / І завтра ж удосвіта в поле - засіймо пустелі» [Муратов 1982:113]. Тим часом у вірші «Три зарубки» трагічні мотиви подані ніби в уснопоетичній інтерпретації. Уже в самій назві закладено напружену внутрішню сутність воєнної ситуації: «Три зарубки на одвірку: / Перша - як минув Оверку / Третій рік. А друга n’ятий. / Третя - як пімов дев'ятий. / А четверту зарубочку / Не зробили топірочком / Вороги, що вранщі-рано / Порубали у лісочку, / Зашморгнули на дубочку / Молодого партизана. / Сорок літ було б Оверку... / Ти ще й досі плачеш гірко, / Сива мати... / В хаті смеркло. / Три зарубки, три зарубки / На дубовому одвірку» [Муратов 1982:242].

У віршах «Червень 1941 року», «Підривники», «Повернення воїна», «Слово до живих», «Прийшли сини до матері» Муратов утверджує великі почуття, а власне, віру в те, що війна, яка минула, - була останньою війною на землі: «Ось воно, / ось воно, / ось воно - $є$ : / Кров'ю здобуте - моє, / Незабутне - моє, / Наче вперше відчуте, / моє-премоє. / Справжнє усе, а не сниться: / Яблуня... / мати... / $i$ сонще / на дні золотої криниці» [Муратов 1982:117].

Одна 3 провідних тенденцій розкриття характерів у літературі про війну полягає в прагненні авторів пов'язати події воєнних років з подіями довоєнними й післявоєнними, вмістити їх у межі ширшого полотна, ніж розповідь лише про воєнні дні [Попов 1985:9]. Іншими словами, провідною мотиваційною естетикофілософською домінантою ліричних творів про Другу світову війну є ідея історичної спадкоємності, що дозволяє поетам глибше розкрити не лише події та факти, а й глибини людського духу, пов'язати в одне ціле обшир подій і масштаби духу учасників війни, показати напруження їхніх дум, устремлінь, почуттів та переживань.

У віршах та поемах, що присвяченні воєнній тематиці, герої I. Муратова, за словами М. Гуменного, потрапляють «в атмосферу особливого виміру часу, коли 
історія починає відраховувати години і хвилини з граничною напругою $і$ залежність від руху історичного часу стає настільки невловною, щуо герої не в змозі звільнитися від його жорстоких обіймів ні на хвилину» [Гуменний 1993:22-23].

Тема війни глибоко й переконливо зреалізована письменником у поемах «Залізом і кров’ю» та «Розчахнута брама». Так, у героїчній сюїті «Залізом і кров’ю» (перша назва - «Запорожці») постають живі образи героїв Другої світової війни, які йшли тяжкими дорогами війни й гинули за Батьківщину. Прикметно, що 1945 року до Спілки письменників України надійшов лист від Владека Раткевича, у якому польський авіаконструктор запитував про домашню адресу I. Муратова та про долю поеми «Запорожці», головні герої якої «патріоти із залізною волею та вірою в краще майбутнє... організують боротьбу не на життя, а на смерть» [Раткевич 1945:3].

Остаточний варіант сюїти складається 3 чотирьох частин, герої яких земляки із Запоріжжя - зустрілися на одній 3 воєнних доріг: танкіст Лобода, старшина Заболотний, снайпер Горіх та директор районного банку Данило Ілліч Гончарук, що пристав до них по дорозі. Письменник змальовує їхні характери й вдачу. Заболотному наснилося, що «по корчах, по камінню без шелесту йде незабутній його батальйон» [Муратов 1967:90]. I навіть коли старшина заспівав, як колись на маневрах, - «Если завтра война», - батальйон його не підтримав. I коли пролунала команда: «Мертві, крок уперед!» [Муратов 1967:91], Заболотний лишився один. «I побачив: бійц̧і проти сонщяя стоять, а від жодного тіні нема» [Муратов 1967:92].

Мерці утворили ніби міст над прірвою, і по них пройшов старшина на той майдан, де молодь без зброї, в барвистих вінках... А як пройшов, «захитався $-i$ в прірву бездонну упав безіменних героїв ланщюг» [Муратов 1967:93].

Можна сказати, що українська поезія взяла на себе завдання «другого прочитання» війни, яке в інших народів, що входили до складу СРСР, виконувала переважно проза: «друге прочитання» війни в українській поезії - це мотив зв’язку часів, вагомість моральних уроків минулого, спадкоємність поколінь [Ільницький 1983:20]. 
У поемі «Розчахнута брама» переконливо й сильно зазвучала мова достовірного документального свідчення. До цієї поеми ввійшли дев’ять віршів разом з інтродукцією та епілогом, написаних у Німеччині в 1942-1944 роках, у концтаборі для полонених на острові Узедом, у селищі Пеенемюнде, решта віршів 1966 року. Вони створили «сильну, не бачену доти в українській поезії емочзійну атмосферу поеми» [Ільницький 1981:42]. Поет завдяки обраній формі зміг поєднати в автобіографічній сюїті драматичні картини оточення й полону з його теперішніми роздумами про пережите. Вражає намальована картина табірного життя, героя ніби знову й знову «пронизують оті балтійські вітри. I вітри солоні, $i$ сіль, яку він добував, - усе було солоним... Його серизе, повне любові до життя, болісно билося при згадці лиш слова Узедом-острова, щуо уособлював тоді смерть» [Ющенко 1993:132]. У «Епілозі» Муратов звертається до часу, - пам’яті, - iз закликом «бути чесною, доброю і світлою» [Муратов 1982:192].

Головним у сюїті стає напружене внутрішнє життя, яким живуть полонені, ті пристрасні бажання, що надають їм сили сміятися ворогам у вічі, не зломитись, не зрадити. У дев’ятому вірші відвертість стає головною домінантною психологічного сприйняття часу - пам’яті: «... I згадує, згадує сериее, / I в нім воскресають / навальні бажання, / Коли приголомшила виждана воля. / I перше бажання було - тікати...» [Муратов 1982:189]. Друге бажання було - наїстись, третє - кричати: «Явільний» [Муратов 1982:190], четверте - забутись, п’яте - помститись, шосте любити «цุе сонц̧е і тепле, й пахуче», «цей берег, чайний ніжний... і свіжу травичку за дротом “ипер-зони”» [Муратов 1982:191], а згодом з'явилося сьоме бажаннязбагнути...

Поет прагне розкрити душу до кінця, без останку, не приховуючи слабкостей. У душі ліричного героя жило й інше почуття, яке допомагало долати наругу й страх. Це почуття, здавалося, готове було погаснути під невсипущим жовтим оком 3 прожекторних вишок оточеного колючим дротом табору, та в останній момент воно виростало з глибин свідомості: «I тим, хто так ревно топтав нас і мучив, / Зирнути у жовті від жаху щуілини / I тімитись, тішитись, тішитись довго, / Аж поки не гримне короткий постріл. / I - далі, і вдертись в їх затишні житла, / Де 
кров моїх кревних на кожнім трофеї. / Де сині арійські баньки з колисок, / 3 рожевих ресорних дитячих / візочків / Безпомічно вирячили на мене / Малі недорощені чінгісхани, / Яких би простив я..» [Муратов 1982:190-191]. Але бажання помсти відступало, як тільки зринали в уяві дитячі візочки - спогад, що буде використаний поетом у «Сповіді солдата», коли він уже тверезо й розсудливо скаже про те, що «наша ненависть не стала безумством месників сліпих» [Муратов 1982:60].

Натомість у поезії «Той час, коли солдатами стаємо» поет утверджує, що оборонцем життя є та людина, котра розумом і серцем усвідомлює єдинокровну спорідненість зі світом: «Солдатами стаєм не в час атаки...», «Солдатами стаєм не перед штурмом...» [Муратов 1982:165], - щоб посилити думку про те, що все життя готує людину до подвигу, до того вирішального моменту, коли вона мусить проявляти свою справжню людську сутність: «Коли коханих до зірок ведемо, / Пізнавши щастя мед і гіркоту, / I в мить оту, врочисту $і$ святу, / Навік ̈̈х оборонияями стаємо» [Муратов 1982:165].

Героїчна сюїта «Партизан Лобода» оспівує героя Другої світової війни, котрий ціною власного життя врятував жителів села: «...живі життям людини, / Що прагне мститись у бою / За честь своєї батьківщчини, / За землю предків, за свою / Любов беззаздрісну $і$ щушру. / За иүі діброви $і$ сади, / За серцฺе друга й командира, / Безсмертне серие Лободи» [Муратов 1967:86]. Поет подає біографічну ретроспективу, наголошуючи на тому, як саме стають героями: «Він був сержантом у піхоті, / Він командиром в лісі став! / Рішучий рух, і голос зичний, / I зір, щзо кличе до атак, / Простий в житті, в легенді вічний, / Спокійний, навіть педантичний, / Грозою названий юнак, / Він спав спокійно перед боєм, / I небезпеку зневажав / Так безоглядно, щуо героєм / Його не кожний би назвав» [Муратов 1967:58].

Устами ліричного героя поет говорить про ставлення Лободи до роботи й до власних обов’язків на війні: «...в роботі був суворий, / Як щзось накаже - не барись; / Але в бою таким відважним, / Таким шаленим був не раз, / Що навіть не взірием для нас / Ставав, а чимось недосяжним. / Аж сам гукне: «На Лободу, / Що 
він не гнеться, не дивіться... / Мене і смерть сама боїться / Тікає геть як я іду!» [Муратов 1967:59] або «він був герой... I щүо иікаво, / Немов народжений для війн, / Військову путь і навіть славу / Сприймав, як щэось минуще» [Муратов 1967:60].

Авторська позиція знаходить своє втілення у всіх подіях, які органічно складають цілісність твору. М. Гуменний, розмірковуючи над авторською позицією у творі, констатує, що «художня дійсність відрізняється від реальної передусім тим, що втілюе в собі душу твория, його ідейно-естетичні позиції, симпатії й антипатії, уявлення про прекрасне $i$ потворне, міру його причетності до порушених проблем» [Гуменний 1994:14].

Принциповим для розуміння поетового ставлення до війни, до іiї героїв $\epsilon$ вірш «А безіменних не було»: «А безіменних не було, - / Ні висоти, ні тих, щэо брали / Ту висоту, слизьку, як скло, / I на вершині помирали. / ... Твердити вагаюсь - / Як звалось ие смертельне скло / До нас. Але заприсягаюсь, / Що безіменних не було» [Муратов 1982:212]. Можна сміливо стверджувати, що і в цій, і в інших поезіях митця репрезентовано духовно-філософські проблеми, які й становлять гуманістичний пафос ліричного доробку поета - твори, присвячені темі війни, пронизані напругою морально-етичних шукань, осмисленням низки фундаментальних питань людського буття під кутом зору воєнної та повоєнної дійсності.

Як бачимо, риси соцреалізму виразно позначились на ліриці Ігоря Муратова, присвяченій темі війни, але, з іншого боку, вірші поета спрямовують читача до питань вічних, а також до свого власного коріння, до української землі.

\section{БІБЛІОГРАФІЯ}

Агеєва 1989 - Агеєва В. Нові виміри воєнної теми / В. Агеєва // Діалектика художнього пошуку: літературний процес 60-80-х років / В. Агеєва, Л. Бойко, Д. Вакуленко, В. Дончик, I. Зуб, Ю. Ковалів, Г. Штонь, В. Моренець. - К., 1989. - С. 207-247.

Гуменний 1993 - Гуменний М. Хронотоп у романах Олеся Гончара / М. Гуменний. // Слово і час. - 1993. - № 8. - С. 22-27. 
Гуменний 1994 - Гуменний М. Авторська позиція в романах Гончара / М. Гуменний. // Дивослово. - 1994. - № 1. - С. 14-17.

Ільницький 1981 - Ільницький М. Нотатки про поезію / М. Ільницький // Радянське літературознавство. - 1981. - № 5. - С. 37-45.

Ільницький 1983 - Ільницький М. Поезія останніх десятиріч: традиції i новаторство / М. Ільницький. // Радянське літературознавство. - 1983. - № 4. C. 13-24.

ІУЛ 1998 - Історія української літератури XX століття: [підручник]; У 2 кн. / За ред. В.Г. Дончика. - К., 1998. - Кн. 2. Друга половина ХХ століття. $456 \mathrm{c}$.

Куцевол 2011 - Куцевол О. Тема Великої Вітчизняної війни у творчості Юрія Шовкопляса (оповідання «Кара», «Хатка на галявині», «Вогняна ніч») / О. Куцевол// Вісник Луганського національного університету імені Тараса Шевченка : Філологічні науки. - Частина 2. - 2011. - № 19 (230). - С. 22-27.

Муратов 1937 - Муратов I. Нездолана Іспанія - Вперед! / I. Муратов. // Літературний журнал. - 1937. - № 8. - С. 66.

Муратов 1941 - Муратов I. Двадцятий полк / І. Муратов. - К., 1941. $63 \mathrm{c}$.

Муратов 1962: Муратов I. Відчувати пульс життя! Нотатки про творче життя письменників Харкова / І. Муратов. // Радянська Україна. - 1962. 14 лютого. - С. 3.

Муратов 1967 - Муратов I. А безіменних не було. Героїка. Лірика / І. Муратов. - Харків, 1967. - 148 с.

Муратов 1967 - Муратов I. Розчахнута брама. Ліричний літопис / I. Муратов. - K., 1967. - 136 с.

Муратов 1972 - Муратов I. Вибрані поезії: у 2 т. / І. Муратов - К., 1972. T. 1. $-1972 .-424 \mathrm{c}$.

Муратов 1982 - Муратов I. Твори: В 4-х т. / I. Муратов. - Т. І. / Передм. М. Ільницького, Упоряд. Н. Білецька-Муратова. - К., 1982. - 415 с. 
Попов 1985 - Попов В. Жива пам'ять поколінь / В. Попов. // Радянське літературознавство. - 1985. - № 5. - С. 9-15.

Раткевич 1945 - Раткевич Вл. Лист до Спілки письменників України / Вл. Раткевич. // Архів Харківського Літературного музею. - Вст. 1604. Д. 420. Сток-Ляцки, 1945. - 4 с.

Ющенко 1993 - Ющенко О. Двічі народжений / О. Ющенко. // Віче. 1993. - C. 131-135. 